\title{
Perspektif Islam Terhadap Ilmu Pengetahuan dan Teknologi
}

\author{
Mohammad Rizky Ramadhandy Budianto ${ }^{1}$, Tresna Ramadhian Setha Wening \\ Galih $^{2}$, dan Syaban Farauq Kurnia ${ }^{3}$ \\ 1,2,3 Jurusan Pendidikan Sistem dan Teknologi Informasi, UPI Kampus Purwakarta \\ e-mail: rizz.higa@upi.edu ${ }^{1}, \underline{\text { tresna101@upi.edu }}^{2}$, syarakuitsuka@,upi.edu ${ }^{3}$
}

\begin{abstract}
ABSTRAK. Saat ini, kemajuan teknologi sudah semakin pesat. Hal ini ditandai dengan Revolusi Industri 4.0 dan Revolusi sosial 5.0 yang membuat bidup semakin mudah babkan hanya dalam 1 genggaman saja. Seiring dengan perkembangan teknologi, Islam harus bisa beradaptasi dengan teknologi yang semakin kesini semakin pesat perubahannya. Hal ini agar eksistensi islam tetap ada di dunia yang semakin cepat teknologinya. Namun, terdapat sebuah pertanyaan besar dimana dengan semakin pesat teknologinya, mau tidak mau islam harus mencari cara agar dengan perkembangan teknologi yang semakin pesat, Islam dapat menjaga ekesistensinya di era modern. Metode penelitian yang akan digunakan yakni kajian literatur dari beberapa karya ilmiah mengenai islam dan teknologi. Penelitian ini berfokus untuk mencari tahu relevansi antara teknologi dan islam di Indonesia. Hasil yang akan dicapai yakni mencari teknologi yang dapat digunakan untuk membantu perkembangan islam di indonesia. Penelitian ini diharapkan dapat berguna bagi para pengembang platform teknologi berbasis islam guna membantu perkembangan islam di dunia modern.
\end{abstract}

Kata kunci: Teknologi Modern, Relevansi, Islam dan Teknologi, Sosial 5.0, Kecerdasan Buatan.

\section{PENDAHULUAN}

Kehidupan manusia sangat dipengaruhi oleh perkembangan ilmu pengetahuan dan teknologi. Misalnya teknologi telah menghasilkan berbagai inovasi dalam mempermudah kegiatan manusia seperti jam, telepon genggam, televisi, kendaraan, dan sebagainya. Saat ini, perkembangan teknologi, khususnya di indonesia sudah semakin pesat. Hal ini dikarenakan perkembangan pada revolusi industri 4.0 dan revolusi sosial 5.0 yang membantu segala aspek kehidupan manusia pada era modern.. Hal ini selaras dengan tujuan dari Revolusi Sosial 5.0 dimana untuk membuat kehidupan bermasyarakat berfokus pada manusia dimana antara pengembangan teknologi dan resolusi dari bermasyarakat sudah dapat diraih dan masyarakat dapat menikmati sebuah kehidupan yang memiliki kualitas hidup yang terbaik dimana sangat aktif dan nyaman (Fukuyama, 2018).

Ilmu pengetahuan dan teknologi dalam era revolusi industri 4.0 dan sosial 5.0 mengalami perubahan yang sangat drastis, sementara agama sendiri mengalami perubahan yang relatif lambat. Hal tersebut terjadi dikarenakan adanya ketidakharmonisan antara ilmu pengetahuan dan agama. Padahal, hakikat ilmu sebenarnya ialah segala ilmu di dunia ini tidak boleh terpisah daripada nilai Islam dan ilmu tersebut baik merupakan ilmu yang terpuji atau ilmu yang terkeji.

Dilansir dari cnnindonesia.com (09/05/2020), Wakil Ketua Lembaga Perguruan Tinggi Nahdlatul Ulama (LPT NU), Dr. Phil. Syafiq Hasyim, MA., untuk menuju 
perkembangan pada iptek dalam islam, hal pertama yang dapat dilakukan yaitu evaluasi dan refleksi terhadap faktor-faktor yang menjadi kemunduran iptek dalam islam. Pertama, salah satunya adalah karena kita jauh dari moral pengetahuan dan ke-Islam-an yang dianjurkan oleh Alquran dan sunnah Nabi, faktor ini sebagai modal utama. Kedua, masyarakat harus menghilangkan pertentangan-pertentangan ideologis dan politik di antara sesama anak manusia dari berbagai bangsa dan negara. Ketiga, masyarakat harus mengembangkan tradisi berpikir, bebas, dan independen. Tradisi ini bisa memicu orang untuk mencari dan menggali informasi dalam rangka membentuk ilmu pengetahuan yang kita kehendaki. Terakhir, masyarakat harus mengembangkan sistem pendidikan yang memperkuat pengetahuan dan kemanusiaan. Dengan cara ini, ilmu pengetahuan yang berkembang dalam Islam tak hanya berguna bagi agama kita, tapi juga berguna bagi kemanusiaan.

Selain itu, islam juga mendorong umatnya agar melakukan penelitian yang juga senantiasa menjadikan Al-Qur'an menjadi sebuah pedoman ilmu pengetahuan. Hal ini jugalah yang mendorong umat muslim harus memiliki sifat-sifat ilmuwan, yakni kritis (QS. Al-Isra/17: 36), terbuka menerima kebenaran dari manapun datangnya ilmu tersebut (QS. Az-Zumar/39: 18), dan senantiasa menggunakan akal pikirannya untuk berpikir secara kritis (QS. Yunus/10: 10). Inilah yang mengantarkan pada sebuah keharusan bagi setiap umat muslim agar mampu unggul dalam bidang Ilmu Pengetahuan dan Teknologi (IPTEK) sebagai sarana kehidupan yang harus diutamakan untuk mencapai kebahagiaan baik di dunia maupun di akhirat QS. Al-Qashash/28: 77; QS. An-Nahl/16: 43; QS. Al-Mujadilah/58: 11; QS. At-Taubah/9: 122).

\section{METODOLOGI}

Penelitian ini menggunakan metodologi sesuai yang apa akan dibahas, yaitu meliputi metode penelitian teknik pengumpulan data, dan juga memiliki batasan masalah yang akan dijelaskan sebagai berikut ini. Penulisan ini menggunakan studi pustaka, Dalam teknik pengumpulan data penulis mengeksplorasi karya tulis ilmiah dan juga beberapa situs kredibel yang membahas topik mengenai Islam dan Teknologi seperti Situs Berita yang kredibel, Karya Tulis Ilmiah yang didapatkan dari beberapa jurnal baik dari Jurnal Islam maupun Jurnal yang bersifat Universal seperti Jurnal Teknologi.

\section{TEMUAN DAN PEMBAHASAN}

\section{Sosial 5.0}

Menurut Fukuyama, Sosial 5.0 membuat kehidupan bermasyarakat berfokus pada manusia dimana antara pengembangan teknologi dan resolusi dari bermasyarakat sudah dapat diraih dan masyarakat dapat menikmati sebuah kehidupan yang memiliki kualitas hidup yang terbaik dimana sangat aktif dan nyaman. Sosial 5.0 pertama kali diperkenalkan di Jepang untuk menjawab tantangan bagaimana kemajuan teknologi harus mengimbangi bagaimana masyarakat harus berkembang seiring teknologi semakin kedepan semakin maju. Sosial 5.0.

Menurut Putra, dengan adanya Sosial 5.0, Kecerdasan Buatan akan berkembang pesat dengan big data yang dikumpulkan melalui internet pada segala bidang kehidupan (the Internet of Things atau IoT) menjadi suatu kearifan baru, yang akan didedikasikan untuk meningkatkan kemampuan manusia membuka peluang-peluang bagi kemanusiaan. 
Perkembangan inilah yang akan membantu seluruh umat manusia agar bisa mendapatkan kualitas hidup yang lebih layak dan juga dengan memperbaiki kualitas hidup, Masyarakat dapat menikmati segala kemudahan hanya dalam satu genggaman.

Dengan Sosial 5.0 juga, Kecerdasan Buatan akan berkolaborasi dengan segala aspek kehidupan yang dimana Kecerdasan akan membantu menyelesaikan segala permasalahan yang terjadi baik dalam sisi Sains Teknologi dan dalam sisi Sosial Humaniora sehingga segala permasalahan yang peneliti masih mencari jawaban atas segala semesta dengan problematika dapat dengan mudah terjawab dengan waktu yang sesingkat-singkatnya.

\section{Revolusi Industri 4.0}

Industri merupakan bagian dari sebuah ekonomi yang memproduksi bahan baku yang dimana sangatlah tinggi dengan mekanisasi dan otomatisasi. Sejak dimulainya industrialisasi, teknologi sudah maju dengan mengarah terhadap pergeseran paradigma yang saat ini sudah terjadi yang disebut "revolusi industri" : dalam bidang mekanisasi (yang juga disebut revolusi industri yang pertama.), kemudian penggunaan intensif terhadap energi listrik (juga disebut revolusi industri yang kedua), dan penyebaran digitalisasi (yang juga disebut revolusi industri 3.0). Dan juga muncul sebuah pemikiran dimana akan direncanakan sebuah rencana untuk "mengingatkan" terhadap software versioning (Revolusi Industri keempat) (Lasi dan kawan-kawan, 2014).

Pada dasarnya dari sebuah digitalisasi yang mutakhir dalam banyak industri, kombinasi teknologi internet dan teknologi berbasis masa depan dalam cakupan objek pintar (mesin dan produksi) terlihat menghasilkan sebuah pergeseran paradigma fundamental baru dalam produksi industri. Pandangan masa produksi di masa depan terdapat sistem manufaktur yang modular dan efisien dan mencirikan skenario dimana produk mengontrol proses manufaktur itu sendiri. Ini berarti untuk merealisasikan manufaktur dalam produk industri dalam sebuah saku ukuran lini produksi dimana menjaga keberlangsungan ekonomi terhadap produk massal.

Perkembangan inilah yang dapat dijadikan sebuah momentum dalam meningkatkan kualitas kompetensi. Pemanfaatan teknologi inilah yang harus diimbangi dengan kemampuan yang akan melahirkan berbagai macam metode efisien yang tertata dengan baik.

\section{Kecerdasan Buatan (Artificial Intelligence)}

Kecerdasan Buatan merupakan bagian bidang ilmu Teknik Informatika yang pesat yang meliputi Data Mining, Pembelajaran Mesin, Jaringan Syaraf Tiruan, pengenalan pola, Sistem pakar, dan topik sejenis lainnya. Kecerdasan Buatan (AI) atau kecerdasan buatan merupakan kecerdasan yang ditambahkan pada suatu sistem atau dengan kata lain kemampuan sistem untuk menerjemahkan data eksternal dengan benar serta mengelola data tersebut dan menggunakan hasil olahan tersebut untuk suatu tujuan tertentu (Goralski \& Tan, 2020; Sousa, Melo, Bermejo, Farias, \& Gomes, 2019).

Kecerdasan Buatan tidak dapat sepenuhnya menggantikan peran manusia, dikarenakan terdapat satu hal yang dimana sebuah Kecerdasan Buatan tidak mampu melakukannya, yakni empati. Namun, Kecerdasan Buatan dapat berperan sebagai pendukung kinerja SDM, oleh karena itu perlunya pengembangan kompetensi oleh SDM yaitu kompetensi yang tidak dapat dilakukan oleh Kecerdasan Buatan dimana salah satunya 
yaitu meningkatkan soft skill SDM dan menyelesaikan masalah yang masih belum dipecahkan dengan manusia selama berabad-abad.

Kecerdasan Buatan diaplikasikan kepada robot yang dimana akan membantu manusia dalam kehidupan sehari hari, saat ini penerapan tersebut sudah dapat kita rasakan pada dunia manufaktur industri yang beberapa sudah mengalami otomasi dengan menggunakan robot.

\section{Kecerdasan Bertambah (Augmented Intelligence)}

Kecerdasan Bertambah menurut Rouse dan Spohrer merupakan sebuah terminologi yang menjelaskan sistem dimana manusia dan kecerdasan buatan bergabung. Terminologi ini selaras dengan kecerdasan buatan, Kecerdasan Bertambah dibekali untuk menambah persepsi manusia dan membantu manusia dalam membuat keputusan, mempelajari dan merencanakan dengan bantuan kecerdasan buatan, ketimbang menggantikan agen manusia dalam proses otomasi dengan kecerdasan buatan.

\section{Teknologi yang saling berkolaborasi dengan islam}

Pada dasarnya, Islam sangat menjunjung umatnya agar senantiasa menjadi orang yang berada baik di dalam maupun di luar panggung mengenai IPTEK. Oleh karenanya, Teknologi turut berkolaborasi dengan islam satu sama lain yang akan berguna untuk seluruh umat, baik umat manusia maupun umat muslim itu sendiri. Hal inilah yang membuat umat muslim harus memiliki sifat-sifat ilmuwan, yakni kritis (QS. Al-Isra/17: 36), terbuka menerima kebenaran dari manapun datangnya ilmu tersebut (QS. Az-Zumar/39: 18), dan senantiasa menggunakan akal pikirannya untuk berpikir secara kritis (QS. Yunus/10: 10). Inilah yang mengantarkan pada sebuah keharusan bagi setiap umat muslim agar mampu unggul dalam bidang Ilmu Pengetahuan dan Teknologi (IPTEK) sebagai sarana kehidupan yang harus diutamakan untuk mencapai kebahagiaan baik di dunia maupun di akhirat QS. Al-Qashash/28: 77; QS. An-Nahl/16: 43; QS. Al-Mujadilah/58: 11; QS. At-Taubah/9: 122).

Dalam hadis Rasulullah S.A.W juga terdapat dorongan untuk menuntut ilmu selaras dengan penekanan dari arti ilmu dalam Al-Quran. Dalam salah satu hadisnya beliau bersabda "barang siapa yang menempuh suatu jalan dalam rangka menuntut ilmu, maka Allah akan melapangkan jalan baginya menuju surga" (HR at-Tirmizi. Beliau pun turut bersabda "Barang siapa yang keluar untuk menuntut ilmu, maka dia berada di jalan Allah sampai ia kembali" (HR at-Tirmizi).

Pada bidang pendidikan misalnya, penggunaan AR untuk membantu untuk menghafalkan ayat suci al-qur'an dan AI pada model pembelajaran daring turut membantu umat muslim dalam memberikan ilmu yang ditransfer dari guru ke murid semakin mudah dan efisien. Selain itu pula, dengan penggunaan AR, pembelajaran Al-Quran, khususnya untuk usia anak-anak akan jauh lebih menarik dibandingkan dengan metode konvensional yang pada umumnya banyak digunakan oleh banyak guru di Indonesia. Media dakwah turut berkembang seiringan dengan pesatnya kemajuan teknologi.

Selain pada bidang pendidikan, dalam bidang penelitian dan pengembangan juga dapat terbantu karena semakin mudahnya penelitian yang awalnya sulit dilaksanakan menjadi sangat mudah. Salah satunya yakni data mining yang membantu dalam mengumpulkan dan juga mengantisipasi dampak yang dapat ditimbulkan oleh media sosial 
(SNS) yang juga akan bergantung pada konsep religi terhadap pengguna media sosial itu sendiri. Selain itu pula, dalam mencari teknologi baru, dapat ditinjau secara ilmiah apakah teknologi tersebut layak atau tidak sesuai dengan teori IPTEK dan juga teori Islam, seperti aplikasi nuklir yang di masa depan mungkin saja menjadi alternatif sumber daya energi listrik di masa yang akan datang. Hasil penelitian tersebut dapat diimplementasikan guna mengetahui fakta dilapangan dan bagaimana cara mengantisipasinya agar kejadian yang buruk dan/atau ketidakefektifan dari suatu metode dapat diminimalisir. Juga diimplementasikan dalam pengembangan teknologi yang dibuat agar dapat membantu sesama umat manusia.

\section{KESIMPULAN}

Di era yang modern, perkembangan teknologi akan semakin pesat dikarenakan majunya bidang ilmu teknologi yang lebih cepat selama 10 tahun kebelakang. Terlebih, Kecerdasan Buatan dan Kecerdasan Bertambah yang dapat membuat sebuah robot semakin cerdas. Selain itu pula, sosial 5.0 dan revolusi industri 4.0 juga turut mendorong pesatnya teknologi karena di masa ini manusia dituntut untuk beradaptasi.

Dalam perspektif islam, islam justru harus mendukung perkembangan teknologi itu sendiri dikarenakan umat muslim harus memiliki sifat-sifat ilmuwan, yakni kritis (QS. AlIsra/17: 36), terbuka menerima kebenaran dari manapun datangnya ilmu tersebut (QS. AzZumar/39: 18), dan senantiasa menggunakan akal pikirannya untuk berpikir secara kritis (QS. Yunus/10: 10). Inilah yang mengantarkan pada sebuah keharusan bagi setiap umat muslim agar mampu unggul dalam bidang Ilmu Pengetahuan dan Teknologi (IPTEK) sebagai sarana kehidupan yang harus diutamakan untuk mencapai kebahagiaan baik di dunia maupun di akhirat (QS. Al-Qashash/28: 77; QS. An-Nahl/16: 43; QS. AlMujadilah/58: 11; QS. At-Taubah/9: 122).

\section{REFERENSI}

Ahmad, H., Zainuddin, N. M. M., Yusoff, R. C. M., Azmi, N. F. M., \& Hassan, W. A. W. 2019. Augmented Reality Model to Aid Al-Quran Memorization for Hearing Impaired Students. In Intelligent and Interactive Computing (pp. 447-457). Springer, Singapore.

Anwar, H. S. 2018. Islam, Ilmu \& Kebudayaan. UAD PRESS.

Baazeem, R. 2020. How religion influences the use of social media: the impact of the online user's religiosity on perceived online privacy and the use of technology in Saudi Arabia (Doctoral dissertation, Kingston University).

CNN Indonesia. 2021. Mengapa Islam Seolah 'Tertinggal' dalam Pengembangan Iptek?. [online] Available at: <https://www.cnnindonesia.com/gayahidup/20200424165738-289-497056/mengapa-islam-seolah-tertinggal-dalampengembangan-iptek $>$ [Accessed 5 March 2021].

Darmalaksana, W. 2021. Science and Technology Opportunities in Hadith Research. International Journal of Islamic Khazanah, 11(1), 41-51. 
Devianto, Y., \& Dwiasnati, S. 2020. Kerangka Kerja Sistem Kecerdasan Buatan dalam Meningkatkan Kompetensi Sumber Daya Manusia Indonesia. InComTech, 10(1), $19-24$.

Dwijo, A. Q. 2014. Pengembangan Iptek dalam Tinjauan Hukum Islam. UIN Sunan Ampel Journal of Islamic Education, 2(1), 144-166.

Elihami, E., \& Saharuddin, A. (2017). Peran Teknologi Pembelajaran Islam Dalam Organisasi Belajar. Edumaspul: Jurnal Pendidikan, 1(1), 1-8.

Fahyuni, E. F. 2017. Teknologi, Informasi, dan Komunikasi (Prinsip dan Aplikasi dalam Studi Pemikiran Islam).

Fukuyama, M. 2018. Society 5.0: Aiming for a new human-centered society. Japan Spotlight, 27, 47-50.

Harto, A. W. 2018. Aplikasi Iptek Nuklir Ditinjau dari Hukum Fiqh Islam.

Hasibuan, N. 2015. Pengembangan pendidikan Islam dengan implikasi teknologi pendidikan. Fitrah: Jurnal Kajian Ilmu-Ilmu Keislaman, 1(2), 189-206.

Hidayat, R., Rahardyanto, S., \& Hardjita, P. W. 2020. Survey Paper: Tantangan dan Peluang Kecerdasan Buatan dalam Bidang Islam, Qur'an dan Hadits. Prosiding Konferensi Integrasi Interkoneksi Islam dan Sains, 2, 343-346.

Ibrahim, M. I., Nazri, F. I., Basiron, B., Baharuddin, A., Bidang, M., Persepsi, K., \& Bentong, S. I. 2018. Islam serta pembentukan sains dan teknologi. In Prosiding Seminar Tamadun Islam UTM (pp. 1-2).

Ilmi, Z. (2012). Islam Sebagai Landasan Perkembangan Ilmu Pengetahuan dan Teknologi. LENTERA, 14(1 JUNI).

Islam, A. T. Sains Teknologi Islam dalam Pembelajaran.

Jasmi, K. A., \& Onn, U. T. M. 2016. Pendidikan sebagai medium penerapan Islam dalam Sains dan teknologi. Pendidikan Sebagai Medium Penerapan Islam Dalam Sains Dan Teknologi.

Lasi, H., Fettke, P., Kemper, H. G., Feld, T., \& Hoffmann, M. 2014. Industry 4.0. Business \& information systems engineering, 6(4), 239-242.

Nasrudin, S. 2017. Islamic Education: A Principle to Develop Religious Society to Anticipate Negative Impact of Social Media. HUNAFA: Jurnal Studia Islamika, 14(1), 59-76.

Nassar, I. A., Hayajneh, J. A., \& Almsafir, M. K. 2013. Relation between social network and Da'wah to Islam: A case study on Jordanian students. International Journal on Islamic Applications in Computer Science and Technology, 1(1), 9-18.

Putra, A. S. 2020. Teknologi Informasi (IT) Sebagai Alat Syiar Budaya Islam Di Bumi Nusantara Indonesia. In SINASIS (Seminar Nasional Sains) (Vol. 1, No. 1).

Putra, P. H. 2019. Tantangan Pendidikan Islam dalam Menghadapi Society 5.0. Islamika: Jurnal Ilmu-Ilmu Keislaman, 19(02), 99-110. 
Rahman, A. 2016. Pengaruh negatif era teknologi informasi dan komunikasi pada remaja (perspektif pendidikan islam). AL-ISHLAH: Jurnal Pendidikan Islam, 14(1).

Ririh, K. R., Laili, N., Wicaksono, A., \& Tsurayya, S. 2020. Studi Komparasi Dan Analisis Swot Pada Implementasi Kecerdasan Buatan (artificial intelligence) Di Indonesia. J@ ti Undip: Jurnal Teknik Industri, 15(2), 122-133.

Rosli, T., Muniandy, Y., Jasmi, K. A., Rosli, T., Muniandy, Y., \& Jasmi, K. A. (2019). Media Sosial dan Impak Tingkah Laku Menurut Islam. Kertas Kerja Dibentangkan di Seminar Sains Teknologi dan Manusia.

Samad, M. 2018. Integrasi Pembelajaran: Bidang Studi Iptek dan Al-Islam. Sunrise Book Store.

Syahri, A. 2018. Spirit Islam dalam teknologi pendidikan di era revolusi industri 4.0. ATTARBIYAH, 28, 62-80.

Tanwir, T., \& Said, H. 2018. Inovasi Pembelajaran Guru Pendidikan Agama Islam Berbasis Teknologi Informasi. KURIOSITAS: Media Komunikasi Sosial dan Keagamaan, 11(2), 189-210.

Toivonen, T., Jormanainen, I., \& Tukiainen, M. 2019. Augmented intelligence in educational data mining. Smart Learning Environments, 6(1), 1-25.

Wahidin, U., \& Syaefuddin, A. 2018. Media Pendidikan dalam Perspektif Pendidikan Islam. Edukasi Islami: Jurnal Pendidikan Islam, 7(01), 47-66. 